\title{
Hubungan Kadar Laktat Serum Inisial dan Skor Pelod pada Anak dengan Sepsis
}

Patricia Y. Gunawan, Ari L. Runtunuwu, Jose M. Mandei, Jeanette I. Ch. Manoppo, Dedi Saputra

Departemen Ilmu Kesehatan Anak Fakultas Kedokteran Universitas Sam Ratulangi/Rumah Sakit Prof. dr .R. D. Kandou, Manado

Latar belakang. Sepsis merupakan masalah kesehatan penting pada anak. Salah satu alat ukur terbaik untuk memperkirakan keparahan penyakit pada anak sepsis adalah skor pediatric logistic organ dysfunction (PELOD). Kadar laktat serum inisial adalah prediktor lain dalam menentukan keparahan penyakit pada anak sepsis yang mudah dilakukan dan hasilnya cepat diperoleh.

Tujuan. Mempelajari hubungan antara kadar laktat serum inisial dan skor PELOD pada anak sepsis.

Metode. Penelitian analitik dari bulan November sampai Desember 2013 di Instalasi Gawat Darurat Anak (IGDA) RS Prof Dr.R.D Kandou, Manado. Sampel darah diambil untuk pemeriksaan laktat dan dihitung skor PELOD untuk tiap pasien. Untuk analisis selanjutnya digunakan korelasi Pearson dan regresi linear, signifikan apabila $\mathrm{p}<0,05$.

Hasil. Terdapat 45 anak sepsis dengan rerata usia 5 tahun. Rerata kadar laktat serum inisial lebih rendah secara bermakna pada pasien yang bertahan hidup dibandingkan pasien yang meninggal $(3,67 \pm 0,92$ berbanding $6,77 \pm 4,62 \mathrm{mmol} / \mathrm{L}, \mathrm{p}=0,013)$. Rerata skor PELOD juga lebih rendah secara bermakna pada pasien yang bertahan hidup dibandingkan pasien yang meninggal $(13,51 \pm 13,16$ berbanding 25,75 $\pm 15,82, \mathrm{p}<0,01)$. Didapatkan korelasi rendah antara kadar laktat serum inisial dan skor PELOD ( $\mathrm{r}=0,42, \mathrm{p}=0,004)$. Kesimpulan. Terdapat korelasi positif rendah antara kadar laktat serum inisial dan skor PELOD pada anak sepsis. Sari Pediatri 2016;18(3):192-7

Kata kunci: laktat inisial, skor PELOD, sepsis, anak

\section{Correlation between Initial Lactate Serum and Pelod Score in Children with Sepsis}

Patricia Y. Gunawan, Ari L. Runtunuwu, Jose M. Mandei, Jeanette I. Ch. Manoppo, Dedi Saputra

Background. Sepsis remains an important health problem in children. One of the best available tools to estimate the severity of illness in critically ill septic children is The Pediatric Logistic Organ Dysfunction (PELOD) score. Early lactate serum is a potentially feasible and clinical useful predictor of mortality in sepsis patients.

Objective. To study the correlation between initial lactate serum and PELOD score in children with sepsis.

Methods. We performed a prospective analytic study from November to December 2013 in Pediatric Intensive Care Unit (PICU) Prof. dr. R. D. Kandou Hospital, Manado. Blood sample was taken for lactate examination and PELOD score for each patient was calculated. Further analysis was done using Pearson correlation and linear regression. Test results were statistically significant if $\mathrm{p}<0.05$. Results. There were 45 children with sepsis, with mean age of 5 years old. Mean initial lactate serum were significantly lower in survivors compared with non-survivors $(3.67 \pm 0.92$ vs $6.77 \pm 4.62 \mathrm{mmol} / \mathrm{L}, \mathrm{p}=0.013)$ and mean PELOD score were also significantly lower in survivors compared with non-survivors $(13.51 \pm 13.16$ vs $25.75 \pm 15.82, \mathrm{p}<0.01)$. We found a significant positive correlation between initial lactate serum and PELOD score $(\mathrm{r}=0.42, \mathrm{p}=0.004)$.

Conclusion. There was a positive correlation between initial lactate serum and PELOD score in children with sepsis. Sari Pediatri 2016;18(3):192-7

Keywords: initial lactate serum, PELOD score, sepsis, children

Alamat Korespondensi: Dr. Patricia Y. Gunawan. Bagian Ilmu Kesehatan Anak FK. Unsrat/ RSU. Prof. Dr. R.D. Kandou. Jl. Raya Tanawangko, Manado, Indonesia. Email: serinashoji@gmail.com 


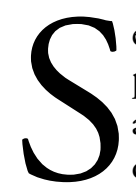
epsis merupakan masalah kesehatan yang penting pada anak. ${ }^{1}$ Menurut WHO, sepsis adalah suatu keadaan klinis akibat infeksi yang disertai dengan takipnea dan takikardia. ${ }^{2}$ Sepsis berat adalah sepsis yang disertai dengan gangguan fungsi organ atau hipoperfusi jaringan. Syok septik adalah sepsis yang disertai dengan hipotensi persisten, walaupun telah diberikan resusitasi cairan secara adekuat. $^{3}$

Sepsis berat dialami oleh $>20.000$ anak tiap tahun di Amerika dengan angka mortalitas mencapai 13\%. ${ }^{4}$ Di Indonesia, mortalitas pada sepsis mencapai 50\%$70 \%$ apabila terjadi syok sepsis dan kegagalan multi organ maka mortalitas naik mencapai $80 \% .^{5}$ Maka pasien sepsis berat harus dibedakan dari pasien lain penyakit infeksi ringan yang masuk di instalasi gawat darurat (IGD). Diagnosis sepsis berat yang cepat dan akurat adalah komponen kritis yang menentukan harapan hidup pada anak sepsis. ${ }^{4}$

Penelitian sebelumnya menemukan bahwa skor pediatric logistic organ dysfunction (PELOD) adalah salah satu alat ukur terbaik yang tersedia untuk memperkirakan keparahan penyakit pada anak dengan sakit kritis, selain pediatric risk of mortality III (PRISMIII) dan pediatric index of mortality II (PIM- II). ${ }^{6}$ Skor PELOD 20 mempunyai probabilitas 50\% untuk terjadinya mortalitas dan makin tinggi skor PELOD makin besar probabililitas terjadinya mortalitas pada anak (sensitivitas 54,5\%, spesifisitas 80,9\%, p<0,05). ${ }^{5,7}$ Akan tetapi, untuk menentukan skor PELOD harus menunggu hasil laboratorium (Tabel 1) sehingga tidak dapat segera ditentukan ketika pasien masuk.

Kadar laktat serum inisial adalah prediktor yang mudah dan berguna dalam menentukan mortalitas pada anak dengan sepsis dan syok septik. ${ }^{8}$ Pada sepsis terjadi suatu keadaan sistemik dan dapat menimbulkan gangguan fungsi organ multipel disertai dengan gangguan oksigenasi ke jaringan, perfusi jaringan yang tidak adekuat dan berkurangnya oksigen di jaringan akan menimbulkan peningkatan produksi kadar laktat serum. Peningkatan kadar laktat serum menunjukkan proses metabolisme anaerob yang berhubungan dengan hipoksia jaringan. ${ }^{9}$ Kadar laktat serum inisial memberikan informasi diagnostik awal akan risiko infeksi bakteri serius pada anak. ${ }^{10}$ Berbeda dengan skor PELOD, kadar laktat serum inisial dapat segera ditentukan ketika pasien masuk. ${ }^{4}$

Masih sangat sedikit penelitian sebelumnya yang menghubungkan antara kadar laktat serum inisial dan skor PELOD pada anak sepsis. Hal ini mendorong peneliti untuk mempelajari hubungan antara kadar laktat serum inisial dengan skor PELOD pada anak dengan sepsis.

\section{Metode}

Dilakukan penelitian analitik hubungan antara kadar laktat serum inisial dengan skor PELOD pada anak dengan sepsis. Subjek penelitian adalah pasien sepsis yang dibawa ke Instalasi Gawat Darurat Anak (IGDA) RS Prof. dr. R. D. Kandou Manado mulai bulan November sampai dengan Desember 2013. Kriteria inklusi adalah anak usia 1 bulan-15 tahun, didiagnosis sepsis berdasarkan kriteria diagnosis sepsis dari International Consensus Conference on Pediatric Sepsis and Organ Dysfunction 2005, dan orang tua pasien setuju untuk ikut serta dan bersedia menandatangani informed consent. Kriteria eksklusi adalah anak dengan gizi buruk, dehidrasi berat, keganasan, luka bakar, trauma, kelainan metabolik bawaan, malaria berat, dan dalam terapi kortikosteroid jangka panjang.

Pemeriksaan kadar laktat serum inisial dilakukan langsung saat pasien masuk ke IGDA dengan cara mengambil darah arteri 20-30 mikroliter (1 tetes darah) kemudian dimasukkan ke stick laktat accutrend ${ }^{\odot}$ oleh petugas yang berpengalaman. Dilakukan pula pemeriksaan fisik dan pemeriksaan darah lengkap yang diperlukan untuk menentukan skor PELOD. Skor PELOD terdiri dari pemeriksaan fisik dan laboratorium yang mewakili 6 sistem organ, yaitu sistem saraf pusat, kardiovaskular, renal, hematologi, dan hepatik (Tabel 1). ${ }^{11}$ Data diolah dengan program SPSS versi 20. Hubungan laktat serum inisial dengan skor PELOD dianalisis dengan korelasi Pearson dan regresi linear. Hasil dikatakan signifikan bila $\mathrm{p}<0,05$. Penelitian ini dilaksanakan di bawah persetujuan Komite Etik Kesehatan dari RS Prof. dr. R. D. Kandou, Manado.

\section{Hasil}

Empatpuluh lima pasien memenuhi kriteria inklusi, $24(53,3 \%)$ di antaranya adalah laki-laki. Terdapat 29 $(64,4 \%)$ pasien hidup (Tabel 2). Infeksi terbanyak yang ditemukan adalah bronkopneumonia, terinci tertera pada Tabel 3. Semua pasien sepsis dengan fokus infeksi 
kombinasi bronkopneumonia, diare akut, dan infeksi susunan saraf pusat (SSP) luaran kasus meninggal. Sementara pasien sepsis yang dirawat dengan fokus infeksi tunggal berupa diare akut dan dengan otitis media tidak ada yang meninggal. Di antara pasien meninggal, terbanyak disebabkan bronkopneumonia dan infeksi SSP $(43,8 \%)$.

Rerata kadar laktat serum inisial yang ditemukan adalah $4,77 \mathrm{mmol} / \mathrm{L}$ dengan rerata pada yang hidup $3,67 \mathrm{mmol} / \mathrm{L}$ dan pada yang meninggal $6,77 \mathrm{mmol} / \mathrm{L}$ $(\mathrm{p}=0,013)$. Rerata skor PELOD adalah 12 , dengan rerata pada yang hidup 13,51 dan pada yang meninggal $25,75(\mathrm{p}<0,01)$. Kami mendapatkan korelasi positif dengan hubungan yang bermakna antara kadar laktat serum inisial dan skor PELOD $(\mathrm{r}=0,42, \mathrm{p}=0,004)$ (Gambar 1).

\section{Pembahasan}

Pada 45 anak dengan sepsis yang diteliti, mayoritas anak laki-laki, rerata usia 20 bulan. Rerata usia yang meninggal lebih muda daripada yang hidup. Penelitian sebelumnya pada anak sepsis di Belanda melaporkan bahwa usia dan jenis kelamin adalah penentu derajat keparahan sepsis. Usia muda secara bermakna berhubungan dengan sepsis yang lebih

Tabel 1. Skor PELOD

\begin{tabular}{|c|c|c|c|c|}
\hline \multirow{2}{*}{ Disfungsi organ dan variabel } & \multicolumn{4}{|c|}{ Sistem skor PELOD } \\
\hline & 1 & 2 & 10 & 20 \\
\hline \multicolumn{5}{|l|}{ Sistem saraf pusat } \\
\hline GCS Pediatri & $12-15$ dan & $7-11$ & 4- 6 atau & 3 \\
\hline Reaksi pupil & Kedua mata reaktif & & $\begin{array}{l}\text { Kedua mata } \\
\text { tidak reaktif }\end{array}$ & \\
\hline \multicolumn{5}{|l|}{ Sistem kardiovaskular } \\
\hline \multicolumn{5}{|l|}{ Denyut nadi, tahun (kali/mnt) } \\
\hline$<12$ & $\leq 195$ & & $>195$ & \\
\hline$\geq 12$ & $\leq 150$ & & $>150$ & \\
\hline \multicolumn{5}{|l|}{ Tekanan darah sistol, (mmHg) } \\
\hline$<1$ bulan & $>65$ & & $35-65$ & $<35$ \\
\hline 1 bulan- 1 tahun & $>75$ & & $35-75$ & $<35$ \\
\hline $1-12$ tahun & $>85$ & & $45-85$ & $<45$ \\
\hline$\geq 12$ tahun & $>95$ & & $55-95$ & $<55$ \\
\hline \multicolumn{5}{|l|}{ Sistem renalis } \\
\hline \multicolumn{5}{|l|}{ Kreatinin (mikromol/L) } \\
\hline$<7$ hari & $<140$ & & $\geq 140$ & \\
\hline 7 hari- 1 tahun & $<55$ & & $\geq 55$ & \\
\hline $1-12$ tahun & $<100$ & & $\geq 100$ & \\
\hline$\geq 12$ tahun & $<140$ & & $\geq 140$ & \\
\hline \multicolumn{5}{|l|}{ Sistem respiratorik } \\
\hline Rasio $\mathrm{PaO} 2(\mathrm{kPa}) / \mathrm{FiO} 2$ & $>9,3$ dan & & $\leq 9,3$ atau & \\
\hline $\mathrm{PaCO} 2(\mathrm{kPa})$ & $\leq 11,7$ & & $>11,7$ & \\
\hline Ventilasi mekanik & Tidak ada & Ventilasi & & \\
\hline \multicolumn{5}{|l|}{ Sistem hematologi } \\
\hline Sel darah putih $\left(\times 10^{9} / \mathrm{L}\right)$ & $\geq 4,5$ dan & $1,5-4,4$ atau & $<1,5$ & \\
\hline Trombosit (x 109/L) & $\geq 35$ & $<35$ & & \\
\hline \multicolumn{5}{|l|}{ Sistem hepatologi } \\
\hline Aspartat transaminase (IU/L) & $<950$ dan & $>950$ atau & & \\
\hline Waktu protrombin (atau INR) & $>60(1,40)$ & $\leq 60(\geq 1,40)$ & & \\
\hline
\end{tabular}


Tabel 2. Karakteristik kasus sepsis anak

\begin{tabular}{|lccc|}
\hline Variabel & Total $($ rerata \pm SB $)$ & Hidup $($ rerata \pm SB) & Meninggal $($ rerata \pm SB $)$ \\
\hline Usia $($ bulan) & $20,11 \pm 25,11$ & $21,38 \pm 28,55$ & $17,81 \pm 17,85$ \\
Nadi $(\mathrm{x} / \mathrm{menit})$ & $147,22 \pm 28,48$ & $135,34 \pm 24,37$ & $168,75 \pm 22,44$ \\
Laju pernafasan $(\mathrm{x} /$ menit $)$ & $55,87 \pm 18,21$ & $54,00 \pm 13,75$ & $59,25 \pm 24,52$ \\
Suhu tubuh $\left({ }^{\circ} \mathrm{C}\right)$ & $37,95 \pm 1,46$ & $38,00 \pm 1,14$ & $37,86 \pm 1,96$ \\
Saturasi oksigen(\%) & $89,24 \pm 8,23$ & $92,97 \pm 3,49$ & $82,48 \pm 3,49$ \\
Hb $(\mathrm{g} / \mathrm{dL})$ & $10,42 \pm 2,34$ & $11,02 \pm 1,67$ & $9,33 \pm 2,97$ \\
Ht $(\%)$ & $30,79 \pm 6,99$ & $32,30 \pm 5,17$ & $28,05 \pm 8,99$ \\
Leukosit $(/ \mu \mathrm{L})$ & $19.447,56 \pm 13.303,17$ & $17.644 \pm 8831,66$ & $22.715,00 \pm 18.864,18$ \\
Trombosit $\left(/ \mathrm{mm}{ }^{3}\right)$ & $343.244,44 \pm 199.862,69$ & $379.275 \pm 177.994,16$ & $277.937,50 \pm 225.772,89$ \\
SGOT $(\mathrm{U} / \mathrm{L})$ & $92,44 \pm 95,19$ & $53,03 \pm 53,26$ & $163,88 \pm 113,32$ \\
SGPT $(\mathrm{U} / \mathrm{L})$ & $55,71 \pm 55,65$ & $34,90 \pm 25,45$ & $93,44 \pm 74,30$ \\
Ureum $(\mathrm{mg} / \mathrm{dL})$ & $31,20 \pm 21,12$ & $23,76 \pm 11,09$ & $44,69 \pm 27,88$ \\
Kreatinin $(\mathrm{mg} / \mathrm{dL})$ & $1,47 \pm 5,89$ & $1,85 \pm 7,34$ & $0,785 \pm 0,64$ \\
Natrium $(\mathrm{mEq} / \mathrm{L})$ & $131,79 \pm 10,06$ & $133,69 \pm 7,51$ & $128,34 \pm 14,00$ \\
Kalium $(\mathrm{mEq} / \mathrm{L})$ & $4,05 \pm 1,08$ & $4,2 \pm 0,91$ & $3,8 \pm 1,34$ \\
Klorida $(\mathrm{mEq} / \mathrm{L})$ & $98,13 \pm 12,78$ & $100,92 \pm 14,20$ & $93,08 \pm 7,78$ \\
Kalsium $(\mathrm{mg} / \mathrm{dL})$ & $7,9 \pm 0,79$ & $8,14 \pm 0,74$ & $7,48 \pm 0,71$ \\
GDS $(\mathrm{mg} / \mathrm{dL})$ & $107,31 \pm 50,28$ & $116,97 \pm 39,33$ & $89,81 \pm 39,33$ \\
Albumin $(\mathrm{g} / \mathrm{dL})$ & $3,51 \pm 0,50$ & $3,71 \pm 0,37$ & $3,16 \pm 0,54$ \\
Lama perawatan (hari) & $8,04 \pm 6,74$ & $10,62 \pm 6,69$ & $3,38 \pm 3,69$ \\
Kadar laktat serum inisial & $4,77 \pm 3,17$ & $3,67 \pm 0,92$ & $6,77 \pm 4,62$ \\
(mmol/L) & $12 \pm 12,30$ & $13,51 \pm 13,16$ & $25,75 \pm 15,82$ \\
Skor PELOD & & &
\end{tabular}

Tabel 3. Fokus infeksi pasien sepsis

\begin{tabular}{lccc}
\hline Fokus infeksi & Total & Hidup & Meninggal \\
\hline BP & 19 & 14 & 5 \\
BP, infeksi SSP & 10 & 3 & 7 \\
Infeksi SSP & 5 & 4 & 1 \\
BP, diare akut & 4 & 3 & 1 \\
Diare akut & 2 & 2 & 0 \\
Otitis media & 2 & 2 & 0 \\
BP, diare akut, infeksi SSP & 2 & 0 & 2 \\
Diare akut, infeksi SSP & 1 & 1 & 0 \\
\hline Jumlah kasus & 45 & 29 & 16 \\
\hline BP
\end{tabular}

$\mathrm{BP}=$ bronkopneumonia, $\mathrm{SSP}=$ susunan saraf pusat 
Patricia Y. Gunawan dkk: Hubungan kadar laktat serum inisial dan skor Pelod pada anak dengan sepsis

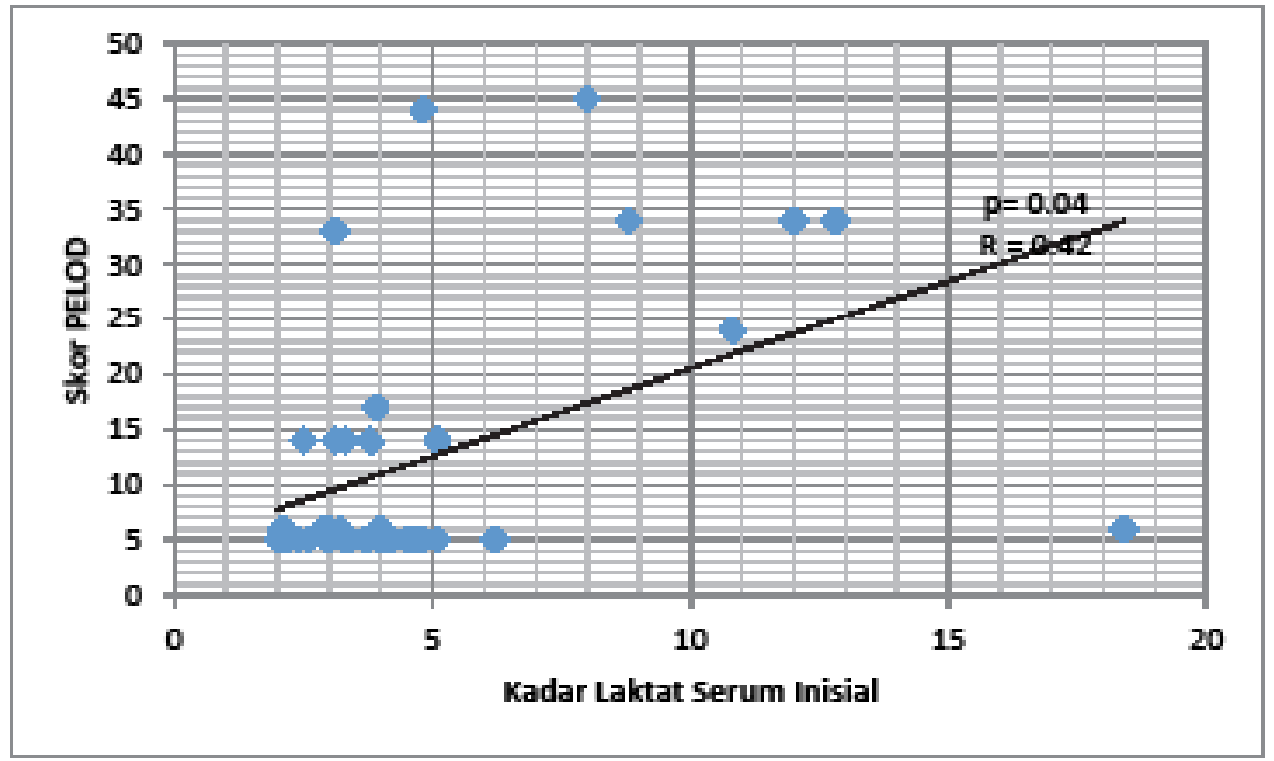

Gambar 1. Grafik hubungan laktat inisial dan skor PELOD

berat dan case fatality rate yang lebih tinggi. Jenis kelamin pria memiliki skor PRISM yang lebih tinggi, lama perawatan di PICU yang lebih lama, dan angka kejadian syok yang lebih tinggi. ${ }^{12}$

Pada penelitian kami, fokus infeksi terbanyak ditemukan adalah bronkopneumonia (42\%). Hasil tersebut mirip dengan penelitian sebelumnya di Philadelphia dan Indonesia yang melaporkan pneumonia sebagai penyebab terbanyak infeksi bakteri berat (masing-masing 14\% dan 48,6\%). ${ }^{4,5}$ Ditemukan pula fokus infeksi terbanyak pada pasien yang meninggal adalah berupa kombinasi antara bronkopneumonia dan infeksi SSP $(43,8 \%)$. $^{5}$ Penelitian lain di Korea melaporkan bahwa gangguan sistem respiratorik, hematologi, dan hepatik lebih sering ditemukan pada pasien. ${ }^{8}$

Kami menemukan rerata kadar laktat inisial serum pada anak sepsis $4,77 \mathrm{mmol} / \mathrm{L}$. Terdapat perbedaan antara kadar laktat serum inisial anak yang hidup dan meninggal. Rerata lama rawat yang pada akhirnya meninggal adalah 3 hari. Hasil tersebut mirip dengan hasil best evidence topic reports (BET) di Universitas Michigan yang melaporkan peningkatan kecenderungan terjadinya mortalitas seiring peningkatan kadar laktat serum inisial, didapatkan $22,4 \%$ pasien dengan laktat inisial $>4$ $\mathrm{mmol} / \mathrm{L}$ meninggal dalam waktu 3 hari. ${ }^{13}$ Kadar laktat serum adalah parameter klinis penting yang mengindikasikan terjadinya hipoperfusi pada pasien sepsis dan dikenal sebagai salah satu penanda mortalitas pada pasien infeksi yang datang di IGD. ${ }^{14}$ Kadar laktat serial juga ditemukan sebagai prediktor kuat terjadinya kegagalan fungsi multiorgan dan kematian. ${ }^{15}$

Meskipun sebagian besar literatur berfokus pada pemeriksaan kadar laktat serum penting dilakukan pada syok septik, sebenarnya semua tipe syok maupun hipoperfusi jaringan dapat menyebabkan peningkatan kadar laktat serum. Laktat adalah produk akhir glikolisis yang terjadi pada kondisi anaerobik, menggambarkan transpor oksigen ke jaringan. Akumulasi laktat terjadi jika sel mengalami hipoksia. Oleh karena itu, semua keadaan yang dapat menyebabkan hipoksia jaringan dapat menyebabkan peningkatan kadar laktat serum, salah satunya adalah bronkopneumonia berat. Hal tersebut menjelaskan satu kasus dengan fokus infeksi bronkopneumonia dengan kadar laktat serum inisial yang tinggi $(18,4 \mathrm{mmol} / \mathrm{L})$ dengan skor PELOD yang rendah (7) (Gambar 1). Selain itu, karena laktat dimetabolisasi di hati dan di ginjal, insufisiensi hati dan ginjal juga dapat meningkatkan kadar laktat. ${ }^{16}$

Rerata skor PELOD pada anak sepsis adalah 12, dengan perbedaan bermakna antara yang hidup dan yang meninggal. Hasil tersebut serupa dengan hasil penelitian di PICU RS Hasan Sadikin, Bandung, 
yang melaporkan bahwa skor PELOD 20 mempunyai kemungkinan terjadinya mortalitas $50 \%$, dan semakin tinggi skor PELOD semakin besar mortalitas pada anak. ${ }^{7}$ Leteurtre $\mathrm{dkk}^{11}$ mengembangkan sistem skor PELOD untuk mengevaluasi derajat keparahan gangguan fungsi organ pada anak yang sakit kritis. Skor PELOD mengevaluasi 6 sistem organ dengan melihat 12 manifestasi klinik dan penemuan laboratorium.

Hasil korelasi positif antara kadar laktat inisial serum dan skor PELOD yang didapatkan sesuai dengan penelitian sebelumnya di Philadelphia yang melaporkan bahwa peningkatan kadar laktat serum berkorelasi positif dengan derajat gangguan fungsi organ, perawatan di ruang rawat intensif, dan perlunya tindakan resusitasi. ${ }^{4}$

Keterbatasan dari penelitian kami adalah kadar laktat serum yang diteliti hanya kadar laktat serum inisial, sementara terdapat beberapa penelitian sebelumnya yang melaporkan pentingnya pemeriksaan kadar laktat serum serial dalam menilai prognosis pada pasien sepsis. ${ }^{8}$ Kekurangan lain adalah tidak dilakukan stratifikasi berat ringannya sepsis, yaitu tidak dibedakan antara sepsis, sepsis berat, dan syok septik.

Kesimpulan dari penelitian kami adalah terdapat korelasi positif rendah antara kadar laktat serum inisial dan skor PELOD pada anak sepsis. Walaupun demikian, hasil penelitian kami menunjukkan peran penting kadar laktat serum inisial dalam memperkirakan skor PELOD dan mortalitas pada anak sepsis. Kami menyarankan untuk dilakukan penelitian lanjutan yang menghubungkan pengukuran kadar laktat serial dan skor PELOD pada pasien sepsis dengan stratifikasi berat ringannya sepsis.

\section{Daftar pustaka}

1. Leclerc F, Leteurtre S, Duhamel A. Cumulative influence of organ dysfunctions and septic state on mortality of critically ill children. Am J Respir Crit Care Med 2005;171:348-53.

2. World Health Organization. The millenium development goals report 2013. New York: United Nations. WHO; 2013.

3. Dellinger RP, Levy MM, Rhodes A. Surviving sepsis campaign:
International guidelines for management of severe sepsis and septic shock: 2012. Crit Care Med 2013;41:580-637.

4. Scott HF, Donoghue AJ, Gaieski DF, dkk. The utility of early lactate testing in undifferentiated pediatric systemic inflammatory response syndrome. Acad Emerg Med 2012;19:1276-80.

5. Hendra, Runtunuwu AL, Manoppo JIC. Pediatric logistic organ dysfunction (PELOD) score as prognosis of multiple organ failure in sepsis. Paediatr Indones 2010;50:226-32.

6. Lacroix J, Cotting J. Severity of illness and organ dysfunction scoring in children. Pediatr Crit Care Med 2005;6:S126-34.

7. Metta D, Soebardja D, Soemasetia DH. The Use of Pediatric Logistic Organ Dysfunction (PELOD) scoring system to determine the prognosis of patients in pediatric intensive care units. Pediatr Indones 2006;46:1-6.

8. Kim YA, Ha EJ, Jhang WK, dkk. Early blood lactate area as a prognostic marker in pediatric septic shock. Intensive Care Med 2013;39:1818-23.

9. Jat KR, Jhamb U, Gupta VK. Serum lactate levels as the predictor of outcome in pediatric septic shock. Indian J Crit Care Med 2011;15:102-7.

10. Vorwerk C, Manias K, Davies F, dkk. Prediction of severe bacterial infection in children with an emergency department diagnosis of infection. Emerg Med J 2011;28:948-51.

11. Leteurtre S, Martinot A, Duhamel A, dkk. Development of a pediatric multiple organ dysfunction score: use of two strategies. Med Decis Making 1999;19:399-410.

12. Maat M, Buysse CMP, Emonts M, dkk. Improved survival of children with sepsis and purpura: effects of age, gender, and era. Critical Care 2007;11:R112.

13. Mercier D. Serum lactate as a marker for mortality in patients presenting to the emergency department with infection. Emerg Med J 2007;42:431-6.

14. Blomkalns, Andra L. Lactate-a marker of sepsis and trauma. Dalam: Advancing the standard of care: cardiovascular and neurovascular emergencies. 2007:43-9. Diunduh dari: www. emcreg.org.

15. Bakker J, Gris P, Coffernils M, dkk. Serial blood lactate levels can predict development of multiple organ failure following septic shock. Am J Surg 1996;171:221-6.

16. Andersen LW, Mackenhauer J, Roberts JC, dkk. Etiology and therapeutic approach to elevated lactate levels. Mayo Clin Proc 2013;88:1127-40. 